\title{
Ontological and Epistemological Implications of Modern Science on Content Materials of Modern Constitution
}

\author{
Syafruddin Muhtamar* \\ PhD Student at Postgraduate Program, Faculty of Law, Hasanuddin University, Indonesia
}

\begin{abstract}
Modern civilization stands firmly on the basis of modern science value. Historically, the modern science is the antithesis of traditional science accros the history of Middle Age and Renaissance. The Middle Age adheres ontologically and epistemologically to divine truth and faith while the Science Modern Age adheres ontologically to materialism human truths and epistemologically to rational, empiricism or objectivism truths. One phenomena of the modern civilization is modern constitutionalism, in practice it puts the constitution as the highest basic law of the constitutional system, and almost all modern states have a constitution as the basis of their constitutional system. Thus, this research tried to analyze the implicative relation of the modern science with the existence of content materials of the modern constitutions, especially in the context of power and human rights. By using the conceptual approach with qualitative analysis, this research found that the ontology and epistemology of the modern science strongly influenced three analyzed constitutions: the American Constitution, the Federal Republic of Germany Constitution and the Indonesian Constitution. In the context of the values of power, the effects of ontology and epistemology of the modern science appear in the practice of separation/division of power in the form of executive, legislative and judiciary institutions; while in the context of the values of human rights the effects of ontology and epistemology of the modern science appear in the significance of human freedom as individual for his/her life where the state cannot further intervene as far as it concerns the freedom of human dignity. In the content materials of the modern constitutions where the effects of ontology and epistemology of the modern science are very significant, there is no room for ontology and epistemology of science based on the metaphysics and faith since it is replaced by human rationality.
\end{abstract}

Keywords: ontology of modern science; epistemology of modern science; modern constitution.

DOI: $10.7176 / \mathrm{JLPG} / 84-15$

Publication date: April $30^{\text {th }} 2019$

\section{Introduction}

Modern civilization is both reality and phenomenon. Its history has lasted almost Nine centuries in human life, from the West (its birthplace) to the East (its imitation). Since the $19^{\text {th }}$ century, the spread from West to East is so hegemonic, through various transmissions, the modern civilization has finally become (as if) the only best choice which must be imitated by the East to realize the future. In the cultural discourse, it is known that the modern civilization has a world view (Muthahhari, 1994) and a distinctive values system, and is the antithesis of the world view and values system of the traditional civilization. The Historians agree that around $1500 \mathrm{~s}$ is the birth of the modern era in Europe. Since then the awareness of the present time has arisen everywhere. Then did people not live in the present time previosly? More precisely, people were less aware that humans could make changes that were qualitatively new, that: hence 'modernity' refers to not only the period, but also a form of awareness related to newness. Thus, the terms change, progress, revolution, and growth, are the key terms of the modern awareness. The notion of modernity as a form of awareness is more fundamental than sociological or economic understanding. In these latest understandings, people refer to the growth of science, engineering, and capitalistic economics as the characteristics of modern society. In contrast, our understanding here is epistemological: what we are interested in is a change in the form of awareness or paradigm. As a form of awareness, the modernity is characterized by three things, namely: subjectivity, criticism, and progress. With subjectivity, it is intended that humans realize themselves as subjectum, i.e. the center of reality which becomes the standard of everything (Hardiman, 2015).

The early phase of the modern period was the $15^{\text {th }}$ century in Europe, based on the 'novelty mindset, through a process of progress attempted qualitatively, both by the revolution pattern and gradual change through growth. The substantial symptom of this modernity is its distinctive epistemological feature, namely the subjectivism awareness, where humans have become the center of all social and individual activities. Even humans become the center of reality and become a standard of everything. This postulate is the most basic of the modernism paradigm, and then it becomes the individualism paradigm, as opposed to the collectivism paradigm which is a characteristic of the previous era, in the classical era. 
Fritjof Capra compared science in the Middle Age with science in the modern age as the following: the nature of science in the Middle Age was very different from its nature in modern science. Science in the Middle Age was based on reasoning and faith and its main purpose is to understand the meaning and significance of everything, and not for forecasting and controlling. The scientists in the Middle Age, who looked for the basic goals underlying various phenomena, considered questions related to God, human spirit, and ethics as questions of high significance. This Middle Age view changed fundamentally in the sixteenth and seventeenth centuries. The definition of the universe as something organic, living, and spiritual is replaced by the understanding that the world is like a machine, and that machine becomes the dominant metaphor in the modern era. This development was caused by the revolutionary changes in physics and astronomy which culminated in the achievements of Copernicus, Galileo, and Newton. The science of the seventeenth century was based on new research methods, developed so strongly by Francis Bacon, by involving mathematical nature description and analytic reasoning method composed by the genius Descartes. With the role of science which greatly determines these major changes, the historians agreed to call the sixteenth and seventeenth centuries the Scientific Revolution Age (Capra 2000).

The effects of ontology and epistemology of the modern science are assumed to affect the material content of modern constitution. This is the main problem of this research, what are the implications of ontology and epistemology of the modern science on modern constitution material content especially in the context of the values of power and human rights? In this research three modern constitutions will be analyzed, namely the American Constitution, the Federal Republic of Germany Constitution, and the Indonesian Constitution.

\section{Ontological and Epistemological Implications of Modern Science on Values of Power in Content materials of Modern Constitution}

Trias Politica is the most influential doctrine of the practice of power separation. The term 'separation of power ' is a translation of the phrase separation of power based on the theory of trias politica or three functions of power. In this connection, it can be considered that the most influential thoughts in making a distinction of the functions of power are John Locke and Montesquieu and at this level it is interpreted as a separation of power. According to Locke about the separation of power: State power is divided into three powers, namely legislative power, executive power and federative power, each of which is separated from one another. Legislative power is the power that makes regulations and laws/acts; executive power is the power that implements the laws/acts and includes judicial power in it (Locke views prosecuting as uitvoering, including the implementation of the laws/acts), and federative power is the power that includes all measures to maintain the state security in relations with other states, such as making alliances (nowadays called as international relations) (Efriza 2016).

Another theory is referring to the idea of Montesquieu who wrote "L'Espirit des Lois" (The Spirit of Law), when describing the 18th century British political system, he established an analysis of the separation of executive, legislative and judicial powers as goals and he described British 'joint constitution' as a commendable effort to uphold the principle of power-overseeing power in order to maintain freedom (Montesquieu 2015). According to Montesquieu: In every government there are three types of power: legislative; executive which handles legal matters between nations; and judiciary which handles civil legal matters. Through the first type, the rulers or authorities established temporary or permanent laws, and changed or revoked the established laws. In the second type he declared war or peace, sent or received ambassadors, enforced public law, and carried out resistance to invasion. In the third type, he punished crime or resolved disputes occurring between individuals. We referred the latter as the judicial power, and previously called the executive power.

According to Efriza, before the separation of power in the state became known, all the powers in the state were centralized and concentrated in the hands of one person, namely in the hands of the Kings/Queens who led the states from generation to generation. How the state power was managed entirely depends on the personal will of the kings/queens without any clear control so that the power did not oppress or negate the people's rights and freedoms. She further said that: In fact, when the Kings' power coincided with the theocratic ideology that used the principle of God's sovereignty, the doctrine of the Kings' power developed to be increasingly absolute. The Kings' voice and will were identical with the God's absolute and undeniable voice and will. In its history, the God's power which was united in the absolute King's power was found in all human civilizations, ranging from Egyptian, Greek, ancient Roman, Chinese, Indian civilization and the experience of Europeans themselves throughout the past to the emergence of the 1957 Church Reformation which had a wide effect with the emergence of the secularist movement that separated the state power and church power explicitly.

It can be understood that the doctrine of separation of powers, both initiated by Locke and Montesquieu, has historically been based on a long history of the practice of one-person centralized governmental power as the practice of power since the 'beginning' of civilization in almost all layers of community, both East and West, 
especially in terms of origin of the theory of power separation by Locke and Montesquieu, the historical setting was the European history itself.

The history of government power in Europe before entering the modern era was the practice of authoritarian and totalitarian governmental power. It could be traced in the bleak history of Middle Age in Europe, when the church organizations' power was very dominant after the fall of Roman Empire. According to Marvin Perry, the Early Middle Age was a period of papacy formation, as well as the community formation in general. Christianity was a unifying principle. After the collapse of the Late Roman Empire, the church gained power and important roles. The Church maintained the Roman administrative system and served as an agent which united and civilized and equipped the people with a conception of life and death that was understandable and meaningful. It was said further that: The Church was the only institution capable of rebuilding civilized life. Throughout the Middle Age, people saw themselves as participants in the great drama of salvation. There was only one divine truth of revelation to human. There was only one way to heaven, and that was through the church. The membership in the universal church replaced the citizenship in universal empire. Crossing Europe, from Italy to Ireland, a new Christiancentered community was formed (Marvin Perry 2012).

The dominance of church authority also eliminated the emperor's power, and the vision of secular empire was forced to adhere to the doctrine of church. This then gave birth to conflict between the secular and spiritual rulers. Both secular and spiritual rulers tended to be feudal in practice. According to C.F. Strong the powerful kings in the Middle Age were those who made every effort to concentrate power in their own hands and also to form a centered control (Strong 2010). As a result of this concentration of power, the authority tended to be tyrannical. Tyranny is a direct cause of the loss of freedom because power is exercised by the will of one person or an institution.

In Europe during the Middle Age there was no alternative 'political theory' for theocratic position of the Pope and Roman Empire. Integration of Christian Europe was very dependent on these authorities. This order has been characterized as an 'international Christian community'. It was described as the first and foremost Christian-self; they surrendered to God as the authority to solve all disputes and conflicts; the main political reference point was religious teaching; and they were always burdened with assumptions about the universal nature of human community that: The Principle of Universe Constitution was first The Almighty God, the absolute One, before and above all World Pluralism, and was the sole source and purpose of each creature. Divine Reason as Regulation for the Universe (Lex aeterna) penetrated all visible pluralisms. The Divine Will was the highest and always be active in a uniform government towards the World, and was the one that directed various kinds to one purpose only (Held 2004).

The practice of pre-modern European history power, both based on the religious and secular doctrine, was basically a power system run by one person both as an emperor or king/queen and as a Pope which in turn raised various turmoils due to the feudal and tyrannical nature that appeared in the practice of government power. The feudalism and tyranny were phenomena of power abuse which had eliminated political freedom in a modern perspective. Therefore Montesquieu in his analysis said: Political freedom could only be obtained in moderate governments: but even in such circumstances freedom could not always be found. Freedom could be found only if there was no abuse of power: but, the fact showed us that everyone who held power would tend to abuse that power; he/she would continue to try to increase his/her power until he/she reached the furthest. Therefore is it not surprising, even it might be true, to say that the virtue itself also needs to be limited? To prevent abuse of power, it is necessary to have provisions that power must be overseen by other power.

Accordingly, the fact that the implementation of power concentrated on one party, which results in the loss of public freedom, is one of the backgrounds of the roots of idea of separating power. Freedom is the main idea that underlies the birth of separation of power. In the past that freedom might belong to a certain group of people, for example the nobles or landlords whose property was arbitrarily confiscated by the emperor, or also that freedom belonged to the people who were oppressed of tyranny, absolute and feudal power. Consequently, in Locke's opinion, individual freedom must be protected by the state, especially because of its freedom to work and own property, that: The state is naturally governed by natural law that everyone must obey as law, gave direction in human life where everyone had freedom and equality, no one might interfere with life, independence or imprisoned others (Azhari 1995). The government is needed to ensure the security of the entire community. The main function of government is to protect the private property rights. In order to avoid the government being a tyranny, executive power must be separated from the legislative.

Based on the historical reality of pre-modern European power which was the background of the theory of separation of power in the modern era, it can be concluded that the main idea behind the theory is human freedom, both in political and economic contexts. It is because in reality, the power that rests on one side (king/queen/pope) 
causes human suffering in the form of the loss of freedom. Freedom is the main issue and idea behind the theory of separation of power by John Locke and Montesquieu.

According to F. Budi hardiman, humanism movement is characterized by belief in human abilities (instead of supernatural abilities), intellectual desires, and appreciation for intellectual discipline. The humanists believe that ratio can do everything and is more important than faith. Since they believe in the intellectual abilities, they also emphasize the importance of social, political and economic changes. They see the absolute power of church increasingly decreases and therefore, there is a tendency to establish national countries. In this situation, they encourage secularization, which is the separation of political and religious power. Humanism in Renaissance Age and modern thought in general have secular essence and prioritizing the human independence to the dimension of divinity and "its freedom" on the earth outside the laws and commands and revelation of God (Nasr 1994).

The practice of separation of power in modern states, if we break down its background of idea, then the separation of power can be interpreted as a rational effort to separate religious truth from human constitutional practice, though the separation of power is only a function of power, yet investigating the roots of the idea of separation theory that refers to human truth and empirical nature as the only standard of truth that can be reduced in the implementation of power or constitutional politics, eliminating the idea of the religious truth. Then the separation of power can also be interpreted as the separation of divine truth from human truth in human political system. This is clearly seen in the American constitution and German constitution; in Indonesian constitution, there is no clause that explicitly states the separation.

The separation of power of modern states ontologically is the separation between the spiritual truth represented in religious teachings (Christian doctrine in the context of pre-modern European history) with pure rational truths represented by the philosophers and scientists, in the power of state. Accordingly, the real nature of secularism appears in the materials of modern constitutions, where the effects of the ontology and epistemology of modern science strongly influence the material contents of the post-modern constitutions. In general, metaphysical, idealistic and spiritual patterns of science are replaced by materialistic, naturalistic science; the center of truth shifts from divinity (Divine, faith) to humanity (natural, ratio). Hence, the human views or knowledge of reality or life also shifts; from the theological to be logical/scientific. This c paradigm is the most decisive basis for various changes to the community activities, including in the context of the statehood.

The idea of individual freedom is the basic idea behind the practice of political modernism. Ideologically, it can be associated with liberalism. Andrew Heywood mentioned: the central theme of liberalism is the commitment to individuals and the desire to build a community in which people can fulfill their interests and achieve fulfillment. The liberals believe that human, first and foremost, are individual beings gifted with reason. This means that every individual should enjoy as much freedom as possible which is consistent with the freedom for everyone. The liberal communities are organized politically around the principles of constitutionalism and agreement, designed to prevent citizens from the government tyranny. The root of liberalism can be traced long before the $19^{\text {th }}$ century; 3 centuries before that ( $15^{\text {th }}$ century) the ideas and theories had emerged and it is a product of the fall of feudalism in Europe. The radical ideas gave rise to British revolution in $17^{\text {th }}$ century, American revolution in 1776, and then French revolution in 1789. The liberals opposed the absolute power of the monarchy based on the doctrine of 'divine rights' possessed by the kings. In order to replace absolutism, the liberals proposed the constitutional government, then the representative government. The central theme "Enlightenment" is the desire to release human from the bonds of superstition and ignorance, and formed "Age of Reason". The expansion of knowledge through the scientific revolution will give human the ability to create their own destiny. Rationality frees human from the grip of the past and the weight of burden and pressure of habit and traditions (Heywood 2016).

\section{Ontological and Epistemological Implications of Modern Science on Values of Human Rights in Content materials of Modern Constitution}

Substantially, the principles of human rights contained in the three constitutions are the same, namely the recognition, appreciation and expectation of basic values of humanity, in its form as human rights. As the constitution compiled in the modern era, it is inevitable to include elements of human rights as its content materials. If it is chronologically described in its history, it appears that the values of human rights in the content materials of the American constitution gets its place more 'positively' after 13 years since its drafting in 1778, in amendment 1 of 1791 . On the other hand, the Federal Republic of Germany constitution places it earlier in the systematics of the content materials of constitution, in section I with so many articles compared to the American Constitution and the Republic of Indonesia constitution, since its drafting in 1945. In addition, in the Republic of Indonesia constitution, the values of human rights is accommodated more quantitatively in amendment 2 (two) of 2000, with special placement in additional chapter, Chapter XA on Human Rights. 
Mashood A. Baderin in his analysis of the universality and universalism of international human rights stated: 'Universality' of human rights refers to the universal or global nature of acceptance of the idea of human rights, while 'universalism' of human rights is related to the interpretation and implementation of the idea of human rights. The universality of human rights has been achieved for several years after the ratification of the Universal Declaration of Human Rights in 1948, and is evidenced by the fact that nowadays the countries that are not strict will be considered as the violators of human rights. Today, all nations and communities acknowledge the idea of human rights, thereby affirming its universality. Nevertheless, the universalism of human rights has not been fully achieved. The universalism implies the existence of the same consensus of universal values in the interpretation and implementation of the international human rights law (Baderin 2007).

The basic question is, where is the position of the effects of ontology and epistemology of modern science on the material contents of the modern constitutions related to the values of human rights. It is necessary to re-analyze the historical thoughts or concepts of human rights then determine the terminology or principal postulation used, so it can show the significance of the effects of ontology and epistemology of modern science.

The variety of literature on the history of human rights explains generally that the roots of the historicity of the idea of human rights used positively in almost all constitutions of the modern states are the history of Western civilization, especially the pre-modern European history, which investigates the classical Greek phase as the roots of the values of Modern civilization in Western world. The idea of human rights played a key role in the late $18^{\text {th }}$ century and early $19^{\text {th }}$ century, in the struggle against the political absolutism. Before the $17^{\text {th }}$ century, Maududi stated that Westerners did not have concepts about the human rights and the citizens' rights. The practical evidence and the implementation of these concepts can only be found at the end of the $18^{\text {th }}$ century, in the proclamation and constitution of the United States and France. Then, in the constitutions of various countries, the references to the human rights began to appear even though somehow the rights given on paper were not given in real life (Abror 2012).

The idea of human rights emerged in the international arena when the dictatorship of kings and feudalists in France exceeded intolerable limits. At that time, the majority of people from the lower classes such as slaves and laborers were mistreated by their employers. At the same time, the kings behaved arbitrarily against the people they employed. Some people appeared to be privileges and enjoying the benefits, while others were only the bearers of the duties and obligations. As a reaction to the above arbitrariness, Fahmi Huwaedi in his work entitled al-IslamalDemocratiyya mentioned that movement of thought emerged to realize independence from elite power who monopolized power and wealth. This movement then gave rise to very popular jargon; Liberte, Egalite`and Fratenite'. The movement led by John Locke (1632-1704) and Jean Jacques Rousseau (1712-1778) led to the rebellion against various dominations of power and arbitrariness, which later gave birth to the French revolution in 1789 (Ismail 2009).

The idea of modern human rights that found its form phenomenally in the early $19^{\text {th }}$ century actually had a interconnectedness of the root of thought that stretched through the Renaissance Age and ancient age of Greek civilization (Qurbani 2016). With the background of the arbitrary governmental power in the pre-modern European history, the idea of human rights found a momentum through the thinkers who fought against the inhumane effects of the practice of the absolute power.

It is known that the historical background of the birth of the idea of human rights was the enactment of the practice of the governmental power which had an effect on the loss of freedom of the general public because of the arbitrary acts of the rulers in the pre-modern European or Western civilization. This condition then made the thinkers and community leaders countered the thought based on the main ideas of equality, freedom and human rights or widelyknown in Latin as Liberte', Egalite' and Fratenite'. However, this idea actually had philosophical roots with the thinkers of Renaissance and Greek classical era. As described by Retno Kusniati (Kusniati 2011): the origin of the idea of human rights comes from the natural rights theory. The natural rights theory originated from the natural law theory. In its development against the power, the Renaissance movement emerged which expected the return of Greek and Roman culture that having respect in individuals. The Renaissance movement was continued by the school of natural law pioneered by Thomas Aquinas and Grotius which emphasized that everyone in life was determined by God, but all people regardless their status were subject to God's authority. It means that not only the power of the King was limited by the divine rules, but also all humans were endowed with unique individual identities; separated from the state where he/she had natural rights which stated that each individual was an autonomous being. In another part, John Locke, a proponent of the natural law, viewed that: all individuals were endowed with the inherent rights of life, freedom, and property which belonged to them and could not be revoked by the state. Through a social contract, the use of their irrevocable rights was given to the authorities, if the ruler decided on the social contract by violating the natural rights of the individual, the people could replace him/her 
with a ruler who was able to respect these rights.

This shift of view was a distinctive feature in the transition of the Middle Age to the Renaissance Age, where later the foundation of the modernism became solid in this Enlightenment century. That human thought in the Middle Age received doctrine from the church. A person's life was always associated with the ultimate goal (eschatology). Human life was essentially determined by God. Consequently, the purpose of human life was to seek for salvation. Thoughts about science were mostly directed at theology. The philosophical thinking is developing, so the scholastic philosophy was born, namely the philosophical movement based on theology and for the religious justification tool. Willingness to escape from the feudal ties emerged to become a free community, including the freedom to break away from the religious ties, so as to find independence for the progress. Anthropocentrism became the view of life with humanism as the mainstream of philosophical thought. Moreover, the support of wealthy merchant family increasingly fueled the spirit of Renaissance to spread throughout Italy and Europe. Renaissance was emerged around the $15^{\text {th }}-16^{\text {th }}$ centuries AD, when the intellectuals, politicians, and artists on the mainland of Europe were simultaneously determined to hold a renewal (Renaissance) movement that wanted freedom of thought to change the religious doctrine which curbed their inner independence (Saifullah 2014).

The humanism view became the center of intellectual resistance to the old ideas of eschatology in the middle age, and humanism became the ontological basis for the modern science, with which later gave birth to a variety of fresh and new ideas for the advancement of modern life, including one human rights concept which then crystallized as a way of life or an example of the modern human life, post religious views considered to curb the human freedom. Humanism placed humanity with its rationality and nature as a standard of truth, both in the context of moral and ethical values. As a result, the view of humanism was often the 'opponents' of the religious views in the pre-modern European history.

\section{Conclusion}

The ontological (materialism/naturalism) and epistemological (positivism) modern science have significant effects on the content materials of modern constitutions. Ontology and epistemology affect strongly on the content materials of modern constitutions in the American constitution, the Federal Republic of Germany Constitution and the Republic of Indonesia Constitution. The practice of separation of power in the material content of these three constitutions is a direct inheritance from the effect of changes in the ontology and epistemology views of modern science; especially regarding the changes in human views towards the center of life. Where in the traditional era, the religious values were dominant; God was the center and orientation of all life activities. While in the modern era, human becomes the center and purpose of life. Based on the ontology and epistemology of modern science, power can no longer be seen as sourced from an abstract/divine being, but from the concrete matter/human. Consequently, the power must be limited, by breaking down the functions in legislative, executive and judicial power. The doctrine of human rights in modern era is a derivative of the idea of humanism which emphasizes human truth as the center of all; putting human freedom as the rationale. As a movement against metaphysics, humanism makes naturalism as its foundation.

\section{References}

Murtadha Muthahhari, (1994), “Pandangan-Dunia Tauhid”. Bandung, Mizan.

F. Budi Hardiman, (2015), “Pemikiran-pemikiran yang Membentuk Dunia Modern”, Jakarta, Erlangga.

Pritjof Capra, (2000), “Titik Balik Peradaban; Sains, Masyarakat dan Kebangkitan Kebudayaan”, Yogyakarta, Bentang Budaya.

Efriza, (2016), “Kekuasaan Politik; Perkembangan Konsep, Analisis dan Kritik”, Malang, Intrans Publishing. Montesquieu, (2015), “The Spirit of Law: Dasar-dasar Ilmu Hukum dan Ilmu Politik”, Bandung, Nusa Media.

Marvin Perry, (2012), "Peradaban Barat dari Zaman Kuno sampai Zaman Pencerahan”, Yogyakarta, Kreasi Wacana.

C.F. Strong, (2010), "Konstitusi-konstitusi Politik Modern: Stusi Perbandingan tentang Sejarah dan Bentuk", Jakarta, Nusa Media.

David Held, (2004), "Demokrasi dan Tatanan Global:dari Negara Modern hingga Pemerintahan Kosmopolitan", Yogyakarta, Pustaka pelajar.

Azhari, (1995), "Negara Hukum Indonesia, Analisis Yuridis Normatif Tentang Unsur-unsurnya”, Jakarta, Ul- Press. Sayyed Hossein Nasr, (1994), “Menjelajah Dunia Modern”, Bandung, Mizan. 
Andrew Heywood, (2016), “Ideologi Politik: Sebuah Pengantar”, Yogyakarta, Pustaka Pelajar.

Mashood A. Baderin, (2007), "Hukum Internasional Hak Asasi Manusia dan Hukum Islam”, Jakarta, Komisi Nasional Hak Asasi Manusia, 2007.

Rabby Habiba Abror, (2012), "Paradoks universalitas HAM Barat di muka cermin Islam perspektif filsafat hukum dan HAM”. Ijtihad, Jurnal Wacana Hukum Islam dan Kemanusiaan, 12 (2), 222-229.

Ismail, (2009), “Hak Asasi Manusia Menurut Perspektif Islam”. Jurnal Asy-Syir'ah, 43 (I), 97-101.

Zainur Abidin Qurbani, (2016), “Islam dan Hak Asasi Manusia; Sebuah Kajian Komprehensif”, Jakarta, Citra.

Retno Kusniati, (2011), “Sejarah perlindungan hak-hak asasi manusia dalam Kaitannya dengan konsepsi negara hukum". Makalah.

Saifullah, (2014), "Renaissance dan Humanisme Sebagai Jembatan Lahirnya Filsafat Modern”. Jurnal Ushuluddin, 21,(2). 